\title{
Contemporary Contemplation on Integrated Global Financial Climate
}

\author{
P.Govindasamy, P.R.Ramakrishnan, H.Premraj
}

\begin{abstract}
Although the global economy nurtured at a noteworthy pace in 2018 (3.7 per cent according IMF and 2.9 per cent according to World Bank) on the back of a strong fiscal expansion in the USA and easy monetary policy by the central banks around the world, the risks to the stance for worldwide economy are tilted downwards on the concerns of monetary tightening cycle and slowdown in the global trade. IMF slashed its global growth outlook from 2019 to 2020 marginally lower to $3.5 \%$ and $3.6 \%$ respectively, mainly due to undesirable properties of tariff gallops ratified in the economies of US and Chinese, and lighter drive in Europe in the post-half yearly of 2018. Growths in the United States are likely to sluggish to 2.5 per cent in 2019 and 1.8 per cent in 2020 as we had compared from 2.9 per cent in 2018. Progression in the Euro area set to moderate from $1.8 \mathrm{per}$ cent in 2018, 1.6 per cent in 2019 and 1.7 per cent in 2020. Japan's economy set to disseminate by 1.1 per cent in 2019 and to 0.5 per cent in 2020.
\end{abstract}

Keywords-Global Financial market, Capital market, Stock indices, etc

\section{I - INTRODUCTION}

The economic position in India remains favourable, supported by vigorous private consumption and gradually more sympathetic fiscal stance and benefits from continuous reforms. The Indian Economic graph expanding April-June' 2018 by $8.2 \%$, dropped during July- Sep'2018 to the level of $7.1 \%$. The result of IMF forecasts shows that Indian Economy has to grow 7.5 per cent in 2019 and 7.7 per cent in 2020. In view of recent evolution of short-term leading economic indicators confirms this positive outlook about our economy. Since Oct- Dec'2017 third quarter of 2017 business confidence indices have steadily ascended, reaching record highs in the second quarter of 2018. While more volatile, PMI indices have also tended to strengthen throughout 2018.

\section{II - OBJECTIVES OF THE STUDY}

To review the global financial market such as overall opinion, current trends, preparation for future focus To interpret the various stock market in the globe and its problems, relationship and review

Revised Manuscript Received on October 22, 2019.

Dr.P.GOVINDASAMY, M.B.A.,PGDCA.,M.Phil.,Ph.D.

Associate Professor, School of Management Studies, Vels Institute of Science, Technology and Advanced Studies(VISTAS), Chennai 600 117, TN, India, E-mail: apgswamy1972@gmail.com

Dr.P.R.RAMAKRISHNAN, M.Com., MBA..,M.Phil.,Ph.D.

Professor and Dean, School of Management Studies, Vels Institute of Science, Technology and Advanced Studies(VISTAS), Chennai 600 117, $\mathrm{TN}$, India

E-mail: dean.sms@velsuniv.ac.in

Dr.H.Premraj, M.Com.,M.Phil., MBA(Fin), MBA(Mktg), M.A.(Yoga), Ph.D. Professor, School of Management Sciences, Vels Institute of Science, Technology and Advanced Studies(VISTAS), Chennai 600 117, TN, India

Email: premraj1960@gmail.com
To verify and compare with Indian major equity and debt market

\section{III - SCOPE OF THE STUDY}

In the US, GDP growth for Quarter three of 2018 was revised down to 3.4 per cent from 3.5 per cent on consumer spending, but still supported by a decent inventory construction. Meanwhile, the headline inflation in US dropped to 1.9 per cent, 11-month low, in December 2018 on back of lower oil prices while the growth in labour market remained strong (unemployment of 3.9 per cent) despite government shutdown in US for 35 days. In a clear change of direction, the Federal Reserve left policy interest rates unchanged within the target rate range of 2.25-2.50 per cent in its monetary policy meeting in January 2019 , after 25 bps hike in the previous month and gave a guidance that it would remain flexible in unwinding of Fed balance sheet and was ready to adjust its normalization policy should the economy and financial markets justify it.

\section{- RESEARCH DESIGN}

The empirical research design has implemented in this study and observed the realistic facts to obtain evidence concerning the current status of the phenomenon to "what exists' with respect to variables or conditions in the current scenario of financial climate. The emphasis of the study was enlightening the numerous dynamics prompting the capital market demanding situations for the industry and investors. Thus, it encompasses the decree of the problem. Selection and development of instrument for gathering the information suits solving the delinquent. We have carefully patterned the facts and formative the design of procedure for data collection, analysis and interpretation.

\section{V - DATA ANALYSIS AND INTERPRETATION}

I. MAJOR GLOBAL FINANCIAL CLIMATE AT A GLANCE

The market interpreted this as dovish commentary from Fed and equity markets around the world rallied. Both developed and emerging market equities gained over 7 per cent in January 2019, boosted further by US-China trade talk. The Eurozone economy grew by 1.2 per cent in the $4^{\text {th }}$ quarter of 2018 , easing from a 1.6 per cent expansion in the previous three- month period, as political turmoil and trade uncertainty weighed on manufacturing and services activity. Among Eurozone's largest economies, France's GDP growth was unchanged, while Spain's economy expanded at a faster pace.

The prospect of the UK having no-deal Brexit in March 2019 and facing a risk of long period of economic slowdown and financial disruption is growing bigger.

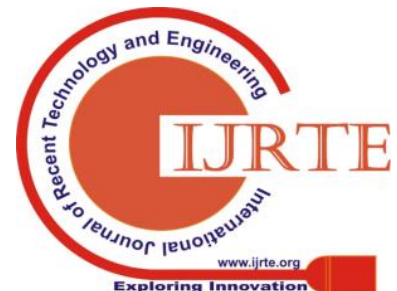


Meanwhile, as prevalent support for a no-deal Brexit have dipped, Norway-style deal, whereas the UK exits but remains in a customs union with EU and enjoying the benefits of single market.

In Japan too, the Bank of Japan maintained its accommodative monetary policy stance and confirmed it optimism on the domestic economy, despite growing uncertainties abroad. 2018 GDP growth of China slowed to $5^{\text {th }}$ successive quarter to 6.4 per cent from 6.5 per cent.

\section{STOCK MARKET INDICES}

Global stocks advanced on signs of progress in U.S.-China trade negotiations and hints that fiscal jerking may be on hold in the U.S. and Europe. Both developed and emerging market equities gained over 7.0 per cent in Jan'2019, constant signals from the US Federal Reserve that it would be more obstinate with further rate rises as well as by the growing optimism over end of trade-war between US and China, as both countries held talks in Jan'2019. Risk-assets recuperated some of the losses they made in the Dec'2018. Uniform political uncertainty remains headwind while recent macroeconomic data proclamations endure to direct assorted signals about the attitude for the worldwide economy. The developed markets equity, as measured by MSCI World Index, shot up 7.7 per cent in Jan'2019, recovering almost all the losses from Dec'2018. Developed markets equity excluding US rose 7 per cent during Jan'2019. The European equity markets grew by 6.1 per cent in Jan'2019, after falling 5.6 per cent in previous month. Emerging markets, as measured by the MSCI Emerging.

Markets Index, also rebounded strongly by 8.7 per cent, mainly on account of rally in the Brazil and Russian equity markets. In the USA, the Dow Jones industrial average index and S\&P 500 index rosette by 7.2 per cent and 7.0 per cent respectively, while technology heavyweight Nasdaq composite index rose by

9.7 per cent during January 2019. Amongst other developed bazaars, Hong Kong's Hang Seng index increase by 8.1 per cent, followed by Germany's DAX index (5.8 per cent), France's CAC index (5.5 per cent), Japan's Nikkei Index (3.8 per cent), and UK's FTSE100 index (3.6 per cent). Amongst the major emerging nations, Russia's RTI Index gained 14.3 per cent, followed by Brazil's IBOVESPA index (10.8 per cent), China's Shanghai Composite index (3.6 per cent), South Africa's JSE all share index (2.7 per cent), and India's Sensex index ( 0.5 per cent).

\section{TABLE-1 STOCK MARKET INDICES}

\begin{tabular}{|c|c|c|c|c|c|c|c|c|}
\hline \multirow[b]{2}{*}{ Country } & \multirow[b]{2}{*}{ Name of the Inder } & \multirow{2}{*}{$\begin{array}{l}\text { Closing } \\
\text { Value } \\
\text { as on } \\
\text { Jan' } \\
31,2019\end{array}$} & \multicolumn{4}{|c|}{ Return ( per cent) } & \multirow[b]{2}{*}{$\begin{array}{l}\text { Annualized } \\
\text { Volatility } \\
\text { (per cent) }\end{array}$} & \multirow[b]{2}{*}{$\begin{array}{l}\text { PIE } \\
\text { Ratio }\end{array}$} \\
\hline & & & 1-Month & 3.-Nonth 6 & 6.1louth 1] & 1.Year & & \\
\hline \multicolumn{9}{|c|}{\begin{tabular}{|l} 
BRICS Nations \\
\end{tabular}} \\
\hline Brazil & BRAZIL IBOVESPA INDEX & 97,394 & 10.8 & 11.4 & 22.9 & 14.7 & 20.7 & 21.8 \\
\hline Russia & RUSSIAN TRADED INDEX & 1,784 & 14.3 & 7.5 & 4.8 & -1.6 & 19.7 & 78 \\
\hline India & Nifty 50 & 10,831 & .0 .3 & 4.3 & -4.6 & -1.8 & 10.6 & 26.3 \\
\hline India & S\&P BSE SENSEXINDEX & 36,257 & 0.5 & 5.3 & -3.6 & 0.8 & 10.3 & 23.8 \\
\hline China & SHANGHAISE COMPOSITE & 2,585 & 3.6 & .0 .7 & .10 .1 & .25 .7 & 9.6 & 17.2 \\
\hline South Aftica & FTSEJSE AFRICA ALL SHR & 54,157 & 2.7 & 3.4 & .5 .7 & .9 .0 & 11.8 & 18.5 \\
\hline \multicolumn{9}{|c|}{$\begin{array}{l}\text { Dereloped } \\
\text { Markets }\end{array}$} \\
\hline USA & NASDAQ CONPOSITE INDEX & 7,282 & 9.7 & .0 .3 & .5 .1 & .1 .8 & 10.5 & 45.5 \\
\hline USA & DOW JONES INDUS. AVG & 25,000 & 7.2 & .0 .5 & .1 .6 & -4.4 & 78 & 21.1 \\
\hline France & CAC 40 INDEX & 4,993 & 5.5 & .2 .0 & .9 .4 & 8.9 & 11.1 & 17.3 \\
\hline Germany & DAXINDEX & 11,173 & 5.8 & .2 .4 & .12 .7 & $-15.3 \mid$ & 11.5 & 15.5 \\
\hline UK & FTSE 100 INDEX & 6,969 & 3.6 & .2 .2 & .10 .1 & .7 .5 & 9.5 & 18.5 \\
\hline Hong Kong & HANG SENG INDEX & 27,942 & 8.1 & 11.9 & .2 .2 & .150 & 12.5 & 13.6 \\
\hline South Korea & KOSPIINDEX & 2,205 & 8.0 & 8.6 & .3 .9 & .14 .1 & 10.0 & 14.6 \\
\hline Japan & NIKKEI 225 & 20,773 & 3.8 & .5 .2 & .7 .9 & .10 .1 & 14.6 & 25.0 \\
\hline Singapore & Straits Times Index STI & 3,190 & 4.0 & 5.7 & .3 .9 & .9 .7 & 8.9 & 11.5 \\
\hline Taivinan & TAIWAN TAIEX INDEX & 9,932 & 2.1 & 1.3 & .10 .2 & .10 .6 & 9.9 & 15.7 \\
\hline
\end{tabular}

Source: Bloomberg, BSE and NSE

\section{TABle A2: Fund Mobilization BY ISSUANCE OF} EQUITY AND BOND IN MAJOR EXCHANGES (US\$ MILLION)

\begin{tabular}{|c|c|c|c|c|c|c|c|}
\hline \multirow[b]{2}{*}{ Country } & \multirow[b]{2}{*}{ Exchange } & \multicolumn{3}{|c|}{$\begin{array}{c}\text { Nov- } \\
18\end{array}$} & \multicolumn{3}{|c|}{ Dec-18 } \\
\hline & & Equity & Bond & Total & Equity & Bond & Total \\
\hline USA & Nasdag - US & 83.8 & $\mathrm{NA}$ & 83.8 & 907.3 & $\mathrm{NA}$ & 907.3 \\
\hline USA & NYSE & $10,150.0$ & $\mathrm{NA}$ & $10,150.0$ & $3,080.0$ & $\mathrm{NA}$. & $3,080.0$ \\
\hline UK & LSE Group & $2,796$. & $52,477.3$ & $55,273.7$ & $2,166.6$ & $33,416.5$ & $35,583.2$ \\
\hline France & Euronest & $2,084.6$ & 0.0 & $2,084.6$ & $13,154.0$ & 0.0 & $13,154.0$ \\
\hline Germany & Deutche Borss AG & 0.0 & 0.0 & 0.0 & 52.2 & 0.0 & 52.2 \\
\hline Spain & BME Spanish Exchanges & $1,671.2$ & $32,542.0$ & $34,213.3$ & 657.0 & $29,074.1$ & $29,731.0$ \\
\hline Japan & Japan Exchange Group Inc. & 0.0 & $5,327.0$ & $5,327.0$ & 0.0 & $\mathrm{NA}$. & 0.0 \\
\hline Singapore & Singapore Exchange & 105.6 & $50,182.9$ & $50,288.5$ & 291.4 & $10,413.7$ & $10,705.2$ \\
\hline Australia & Australian Securities Exchange & $2,447$. & $\mathrm{NA}$ & $2,447.4$ & $3,586.4$ & $\mathrm{NA}$ & $3,586.4$ \\
\hline Hong Kong & Hong Kons Exchanges and Clearing & 3.440. & 10.924 .6 & 14.365 .3 & 4.772 .5 & 13.296 .1 & 18.068 .6 \\
\hline Korea & Korea Exchange & 352. & $37,264.0$ & $37,616.4$ & 399.4 & $30,781.4$ & $31,180.7$ \\
\hline Brazil & BM\&FBOVESPA S.A. & 0.0 & 101.7 & 101.7 & 601.9 & 0.0 & 601.9 \\
\hline Russia & Moscow Exchange & $\mathrm{NA}$ & $27,206.7$ & $27,206.7$ & NA & $19,370.1$ & $19,370.1$ \\
\hline India & BSE India Limited & 0.0 & 551.9 & 551.9 & 311.2 & 834.4 & $1,145.6$ \\
\hline India & NSE India Limited & $2,570.8$ & $26,260.5$ & $28,831.3$ & 548.3 & $27,746.3$ & $28,294.6$ \\
\hline China & Shanghai Stock Exchange & $2,428$. & $\mathrm{NA}$ & $2,428.1$ & $2,412.9$ & $\mathrm{NA}$. & $2,412.9$ \\
\hline China & Shenzhen Stock Exchange & $2,481$. & $3,844.0$ & $6,325.3$ & $7,217.8$ & $4,828.0$ & $12,045.8$ \\
\hline South Africa & Johannesburg Stock Exchange & 156.0 & $\begin{array}{l}\text { d } 16.468 .8 \\
\text { d }\end{array}$ & \begin{tabular}{l|l}
8 & 16.624 .8 \\
8
\end{tabular} & 103.5 & 3.491 .4 & 3.594 .9 \\
\hline
\end{tabular}

FUND MOBILIZATION BY ISSUANCE OF EQUITY AND BOND: As per the data available from World Federation of Exchanges refer Table- 2, major exchanges raised $\$ 40.3$ billion in equity (compared to $\$ 30.8$ billion previous month) and $\$ 213.5$ billion in debt (compared to $\$ 293.9$ billion in previous month). On equity side, Euronext saw the majority share of $\$ 13.2$ billion in the total resource mobilization during December 
2019, followed by Shenzhen Stock Exchange (\$ 7.2 billion), Hong Kong exchange (\$ 4.8 billion), Australian Securities Exchange (\$ 3.6 billion), NYSE (\$ 3.1 billion), Shanghai Stock Exchange ( $\$ 2.4$ billion), and LSE group (\$ 2.2 billion). On the debt side, LSE witnessed the largest fund raising of $\$ 33.4$ billion during December 2018, followed by Korea exchange ( $\$ 30.8$ billion), BME Spanish (\$29 billion), and NSE India (\$27.7 billion).

\section{VI- CONCLUSION}

The International Monetary Fund has forecast the global economy and viewed that 3.7 per cent, 3.5 per cent and 3.6 per cent in 2018, 2019 and 2020 respectively. On account of trade-war there has been a further downward revision in the world- wide progression prediction for 2019 and 2020, slowdown in the advanced economies especially the euro area and weakening financial market sentiment and greater than envisaged slowdown in China has however, the IMF has forecast that India's economy poised to pick-up in 2019, benefiting from lower oil prices and a slower pace of monetary tightening than previously expected and inflation pressures drive move to comfort zone. India after an estimated growth of 7.3 percent in 2018 have projected to grow at 7.5 per cent in 2019 and 7.7 per cent in 2020, an upward revision in the growth forecast for 2019 and while leaving the 2020 growth forecast unchanged. Retail inflation in India stood at 2.05 per cent (provisional) in January 2019 , on falling food and fuel prices. India's overall exports (both manufacturing and services) in April-Dec'2018 were estimated to be US\$ 396.73 billion, demonstrating positive growth of 13.79 per cent compared with the same period last year. Overall imports in April-Dec'2018 were estimated to be US\$ 479.46 billion and revealing positive growth of 14.63 per cent associated over the same period last year.

\section{REFERENCE}

1. National Institute of Securities Market (NISM), An educational initiative of SEBI, Investment Advisor, reprint-2016.

2. World Economic Out- look (WEO) Feb-2018

3. SEBI Annual Report 2017-18

4. IMF projection 2018-19

5. Central Statistical Organization 2017-18

6. Economic Environment and Investment Climatic Conditions, Govindasamy, P. Premraj, H. in International Journal of Research in Engineering, IT and Social Sciences, P.9-16

7. Price Volatility of the Gold Commodity Using Technical Analysis with reference to Rayalseema Bullion Commtrade Pvt.Ltd., P.Govindasamy in International Journal of Mechanical and Production Engineering Research \& Development, P.423-429

8. 8. Govindasamy, D. P., \& Premraj, D. (2019). An Analytical Study On Financial Planning And Strategy Formulation. Restaurant Business, 118(9), 28-34.

9. https://doi.org/10.26643/rb.v118i9.7922 